\title{
Suitability Evaluation of Groundwater Quality for the Intent of Irrigation
}

\author{
G. Shyamala $\uparrow *$, K. Rajesh Kumar**, R. Gobinath* and N. Saravanakumar**** \\ *Department of Civil Engineering, S R Engineering College, Warangal, India \\ **Centre for Construction Methods and Materials, Department of Civil Engineering, S. R. Engineering College, \\ Warangal, India \\ ***Arba Minch University, Sawla Campus, Ethiopia \\ †Corresponding author: G. Shyamala; civilshyamala@gmail.com
}

Nat. Env. \& Poll. Tech. Website: www.neptjournal.com

Received: 28-03-2020

Revised: 23-04-2020

Accepted: $27-05-2020$

Key Words:

Groundwater quality Irrigation

Sodium adsorption ratio SAR

\begin{abstract}
Exploration was conducted in the study area of Coimbatore district by collecting 60 samples from the agricultural belt. The groundwater is neutral to alkaline in character with $\mathrm{pH}$ varying from 6.70 to 9.02 among the mean of 7.37. Elevated electrical conductivity (EC) was observed in upstream parts of the study area. Water quality for irrigation is determined by several key components like electrical conductivity (EC), total suspended solids (TDS), residual sodium carbonate (RSC), chloro alkali Indices (CA I \& CAII), sodium adsorption ratio (SAR), percent sodium (\%Na), Kelley's ratio (KR), magnesium hazard (MH), permeability index (PI) and soluble sodium percent (SSP). In total, six samples were found to be with high salinity hazard. The mean value of SAR was found to be 5.24, maximum sample falls under $\mathrm{C} 2 \mathrm{~S} 1$ to $\mathrm{C} 4 \mathrm{~S} 1$ category as per USSL Salinity diagram. As per Piper diagram in the anionic regime, $\mathrm{Cl}$ dominates $\mathrm{HCO}_{3}^{-}, \mathrm{CO}_{3}^{2-}$ and $\mathrm{SO}_{4}^{2-}$. Higher magnesium hazard in the groundwater is owing to the consequence of dyeing and bleaching industries. Magnesium hazard value indicates that 51 samples out of 60 are unsuitable for irrigation. According to the study, it is revealed that groundwater in the study area is contaminated by both natural factors and anthropogenic activities.
\end{abstract}

\section{INTRODUCTION}

Characteristics of water based quality are gaining extraordinary significance with the ascent in the number of sectors and for agribusiness. Sufficient measure of water is significant for a legitimate yield of plants, yet the quality of water utilized for water system should be well within the standards as far as possible, else it could unfavourably influence the plant yield. Questions have been raised with regards to the social and natural supportability of this escalated method of yield creation, i.e. the source of water for irrigation as groundwater (Shyamala et al. 2008). Groundwater quality is considered of great importance with rapid industrialization. Deterioration in groundwater quality has an adverse impact on plant growth. Soil becomes saline and the permeability of soil decreases if the inferior water is used continuously without proper drainage for irrigation purpose. The quality of crop and yield are affected by irrigation water quality. The water utilized for the water system is a crucial factor for improving the yield and nature of irrigated plants. The agricultural water quality relies basically upon the presence of dissolved salts and their intensity.

Ayuba et al. (2013) carried out a preliminary survey by analysing the topography map of Enugur metropolis before sampling. The test wells are twist drill-bored and hand-burrowed wells with breadth extending from 0.7 to 0.9 $\mathrm{m}$ in all the three settlement zones. Groundwater samples of 42 numbers were collected from Erugur metropolis. Piper diagram and scatter plot for the three settlement areas were analysed (Ramesh et al. 2020). The study reasoned that the groundwater extricated from the location of low contamination stacking is probably going to be more secure and increasingly consumable when contrasted with those of the other contamination types.

Basamba et al. (2013) concluded that the worsening of freshwater is a global problem. The demand for clean water is based on the increase in population growth and the living standard of people. Most of the study areas have good potable water, except a few which are contaminated by faecal contamination (Shyamala et al. 2019). Al-ahmadi (2013) studied groundwater table in western Saudi Arabia in which he found the water table at superficial depth ranges from 1.08 to $2.40 \mathrm{~m}$. Samples were procured from the Wadi and tested in the laboratory for major cation and anion composition. Groundwater has been assessed for potability and irrigation purposes based on salinity and sodium hazard and total dissolved solids. Ramkumar et al. (2013) conducted studies to appraise the hydrogeochemical properties of water of Kottur block, Thiruvarur district, Tamil Nadu. Predom- 
inance of cations in the range for $\mathrm{Na}^{+}>\mathrm{Ca}^{2+}>\mathrm{K}^{+}>\mathrm{Mg}^{2+}$ and anions $\mathrm{Cl}^{-}>\mathrm{SO}_{4}{ }^{2-}>\mathrm{HCO}_{3}{ }^{-}>\mathrm{NO}_{3}{ }^{-}$was seen in the two seasons. From flautist trilinear outline it is seen that most groundwater tests are $\mathrm{Na}^{+}-\mathrm{Cl}^{-}$and $\mathrm{Ca}^{2+}-\mathrm{Mg}^{2+}-\mathrm{SO}_{4}{ }^{2-}$. It is obvious from the Wilcox graph that tests that tumble from low to high, saltiness threat is not reasonable for rural areas. Kelly's proportion and magnesium proportion demonstrates that most examples are appropriate for water system reason.

The $\mathrm{pH}$ range of groundwater diverse from 7.6 to 8.4 , the electrical conductivity was found between 2992 and 2894 $\mathrm{mmho} / \mathrm{cm}$ at $26^{\circ} \mathrm{C}$ in the study area. Salifu et al. (2015) conducted groundwater hydrogeochemical analysis based on water quality for irrigation. RSC was used to discover the appropriateness of groundwater for water system use. The USSL graph result uncovers that the examples fall in the classification, which demonstrates high to high saltiness.

All three seasons indicate reverse ion exchange parameters of calcium and magnesium with the majority of rich components in groundwater (Shyamala et al. 2008). Quality of groundwater was analysed for 23 samples with irrigation water quality standards Wilcox, USSL (Sappa et al. 2014). Groundwater quality and its appropriateness for agriculture and domestic activity were inspected by different physico-synthetic parameters, for example, $\mathrm{pH}$, total hardness, electrical conductivity, total dissolved solids, total hardness, calcium, magnesium, potassium, sodium, bicarbonate, sulphate and chloride (Ahamed et al. 2015). Percolation of water in the soil was condensed as the sodium content of the water reacts with the soil chemicals which are naturally present. The arrangement of the soil grains was also destructed and the physical properties get altered (Shyamala et al.2016). Alkali soils are formed when sodium reacts with carbonate and saline soil was formed when sodium reacts with chloride, both of the soils do not favour the growth of plants (Srinivas et al. 2015). $\mathrm{HCO}_{3}{ }^{-}$combines with $\mathrm{Ca}^{2+}$ and $\mathrm{Mg}^{2+}$ and the concentration gets elevated (Krishnasamy et al. 2020).

High SAR in irrigation water transforms the physical construction of the soil particles. Soil particles are attracted towards sodium and adsorbed on the surface, making soil impervious (Mohamed et al. 2018). High EC content in the irrigation water reduces the ion intake capacity of plant roots from the soil, which results in the reduction of crop yield (Srinivasamoorthy et al. 2012). Even if the moisture content of the soil is high, the plant would not be able to absorb the moisture and nutrients required for growth. Salinity condition exists as salts get accumulated in the root zone of the plants if the groundwater with high TDS is used for irrigation continuously. In saline solution, crops are unable to extract water and subsequently, the yield gets reduced. Ion exchange between the water quality parameters is denoted by CAI. Positive CAI indicates that there is no exchange of ions between $\mathrm{Na}^{+} \mathrm{K}^{+}$and $\mathrm{Ca}^{2+} \mathrm{Mg}^{2+}$. Shanmugasundharam et al. (2015) used the Wilcox diagram to determine the aptness of groundwater for irrigation purpose. He computed sodium Kelley ratio, adsorption ratio, magnesium hazard, percentage sodium permeability index and residual sodium carbonate (RSC) along with Wilcox diagram and USSL diagram. High salinity was observed in most of the location, hence ample drainage should be provided to improve crop yield (Shyamala et al. 2020, Shyamala \& Jeyanthi 2017). Water quality in the area Godavari Upazila was analysed for agricultural application impact due to irrigating with polluted water which may lead to toxicity; salinity and affect water infiltration rate factor analysis was performed using XLSTAT Version 2013.6.03. The objective of the research is to analyse the groundwater quality in the Coimbatore district and determine its suitability for irrigation purpose.

\section{MATERIALS AND METHODS}

\section{Study Area}

Mettupalayam, the investigation area, is situated on the foot slopes of Nilgiris, India. The Bhavani River situated in the lower regions of Nilgiris, located in the Western Ghats is the perpetual stream in India. Lately, numerous ventures have been set up at the spring limit of Bhavani River, which has the perennial flow of water to the individuals in the taluk. Different sources incorporate borehole and hand-wells, and channel water. The selected study area is a significant exchanging centre and travel community for slope products. This study was attempted by arbitrarily gathering 60 groundwater tests from open wells inside Mettupalayam, India. The investigation zone and the sample areas are introduced in Fig. 1. The samples were gathered in plastic containers, sanitized with distilled water before gathering the groundwater samples.

\section{RESULTS AND DISCUSSION}

\section{Irrigation Water Quality Parameters}

The groundwater samples were analysed following standard methods recommended by APHA (1998). The colour and odour of the samples were observed physically. The $\mathrm{pH}$, Total Dissolved Solids (TDS), Electrical Conductivity (EC) and temperature were analysed on-site using digital meters. Other parameters such as turbidity, Total Solids (TS), Total Suspended Solids (TSS), Total Hardness (TH), calcium hardness, magnesium hardness, sodium, potassium, sulphate, chlorides, carbonate and bicarbonates, ammonia, iron, chromium, and fluoride were determined in the laboratory by the volumetric and instrumental methods. The quality 


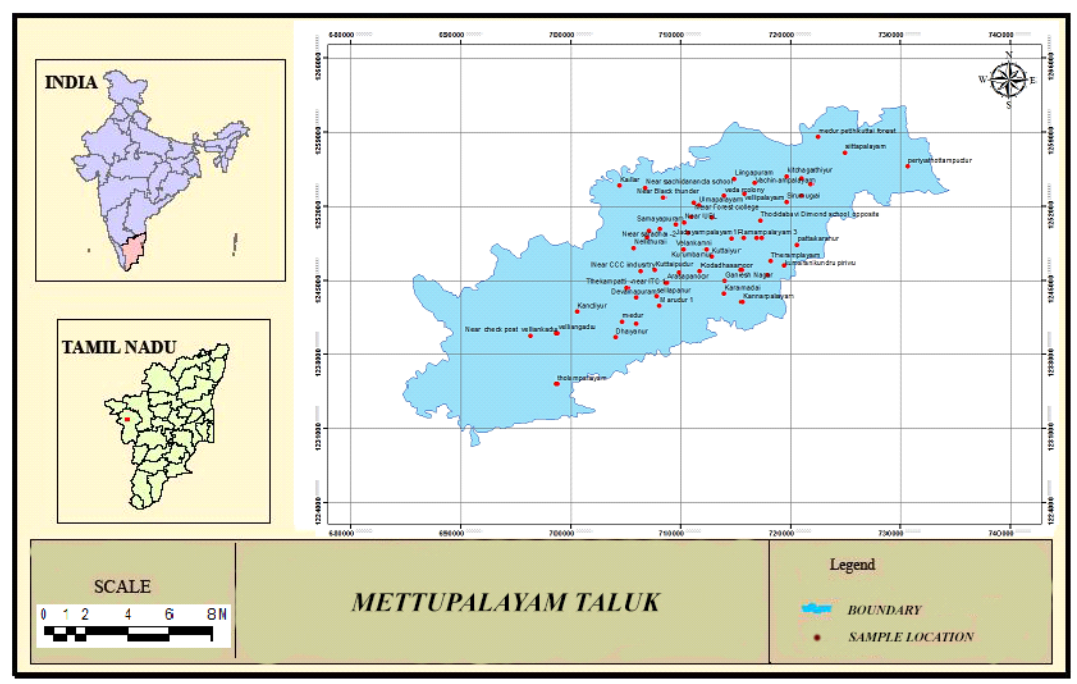

Fig. 1: The study area.

of sampled groundwater was compared with BIS (2009) standards. Quality of water for irrigation is determined by several key factors like Residual Sodium Carbonate (RSC), Chloro Alkali Indices (CA I \& CAII), Sodium Adsorption Ratio (SAR), percent sodium (\%Na), Kelley's Ratio (KR), Magnesium Hazard (MH), Permeability Index (PI) and Soluble Sodium Percent (SSP) as given in Table 1.

\section{Salinity Hazard}

$\mathrm{EC}$ is an upright quantity of saltiness danger to crops as it reflects total dissolved solids in groundwater. Elevated EC shows high salt substance water. Overabundance saltiness will decrease the osmotic movement of plants. Ions may be positively or negatively charged, which are produced by breaking compounds that conduct electricity. The mobility of ions dissolved in water increases conductivity.

Total dissolved solids can be indirectly measured from electrical conductivity. The limiting values for electrical conductivity are provided in Table 2 . Out of 60 samples tested,

Table 1: Minimum and maximum value of irrigation water quality parameters.

\begin{tabular}{|lllll|}
\hline S.No. & Variable & Minimum & Maximum & Mean \\
\hline 1 & SAR & 1.81 & 9.30 & 5.24 \\
2 & $\% \mathrm{Na}$ & 17.088 & 52.52 & 38.76 \\
3 & RCS (meq/L) & 0.134 & 1.32 & 0.425 \\
4 & KR & 0.123 & 0.706 & 0.375 \\
5 & MH & 36.56 & 77.44 & 57.31 \\
6 & CA I & -17.64 & 0.47 & -1.054 \\
7 & CA II & -0.964 & 3.643 & 0.542 \\
8 & SSP & 10.8564 & 41.369 & 25.62 \\
9 & PI & 21.076 & 77.939 & 41.889 \\
\hline
\end{tabular}

none of the samples is in the category of low or medium. High electrical conductivity is observed in 54 samples and 6 samples are of very high electrical conductivity, i.e. in the range greater than $2250 \mu \mathrm{S} / \mathrm{cm}$ as shown in Fig. 2.

Table 2: Categorization of irrigation water quality based on EC.

\begin{tabular}{|llll|}
\hline S.No & Limiting value & category & No. of samples \\
\hline 1. & $<250(\mu \mathrm{S} / \mathrm{cm})$ & Low & - \\
2. & $250-750 \mu \mathrm{S} / \mathrm{cm})$ & Medium & - \\
3. & $750-2250(\mu \mathrm{S} / \mathrm{cm})$ & High & 54 \\
4. & $>2250(\mu \mathrm{S} / \mathrm{cm})$ & Very high & 6 \\
\hline
\end{tabular}

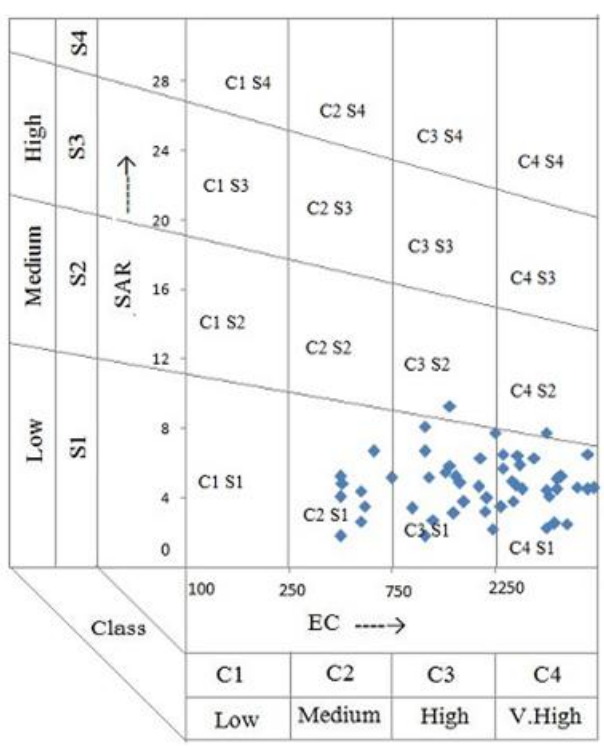

Fig. 2: USSL diagram for Salinity Hazard. 


\section{Total Dissolved Solids}

Groundwater contains a negligible quantity of suspended solid as these are filtered out by soil strata through mechanical straining action. The amount of dissolved solids in groundwater increases with the input of manmade contamination. Total dissolved solids in the study location are given in Table 3. In 60 samples considered for analysis 58 samples are fit for agricultural usage and 2 samples are unfit for both potable and agricultural usage. The presence of total dissolved solids is owing to the sediments or the contact of water with the atmosphere or soil.

\section{Sodium Adsorption Ratio}

The Sodium Adsorption Ratio (SAR) shows the impact of relative cation fixation on sodium build up in the soil; consequently, sodium adsorption proportion (SAR) is another technique for deciding the impact of sodium.

Suitability of groundwater for agricultural use is found by Sodium Adsorption Ratio. Continuous use of water with high SAR may cause a prolonged dent to soil. Due to the formation of stable aggregates, the soil structure is affected. Permeability of soil is reduced and in turn, crop yield is decreased. Sodium adsorption ratio (SAR) is computed by the following formula 1.

$$
\mathrm{SAR}=\frac{\mathrm{Na}^{+}}{\sqrt{\left(\mathrm{Ca}^{2+}+\mathrm{Mg}^{2+}\right) / 2}}
$$

If the SAR is less than 3.0 the groundwater can be used for all varieties of crops. For sensitive crop, the usage should be minimized if SAR value is in the range of 3-6. Categorization of groundwater based on SAR is given in Table 4 .

\section{Percent Sodium}

Presence of sodium in groundwater is represented by soluble sodium or percent sodium. Sodium percent is classified

Table 3: Categorization of irrigation water quality based on TDS.

\begin{tabular}{|llll|}
\hline S.No & $\begin{array}{l}\text { Limiting } \\
\text { value }\end{array}$ & Category & $\begin{array}{l}\text { No. of } \\
\text { samples }\end{array}$ \\
\hline 1 & $<500$ & Fit for drinking & - \\
2 & $500-1000$ & Unfit for drinking & 14 \\
3 & $<3000$ & Useful for irrigation & 44 \\
4 & $>3000$ & Unfit for drinking and irrigation & 2 \\
\hline
\end{tabular}

Table 4: Categorization of irrigation water quality based on SAR.

\begin{tabular}{|llll|}
\hline S.No & Limiting value & category & No. of samples \\
\hline 1 & $0-3$ & No problems & 45 \\
2 & $3-6$ & Moderate problems & 15 \\
3 & $>6$ & Severe problems & 0 \\
\hline
\end{tabular}

Table 5: Categorization of irrigation water quality based on Percent sodium.

\begin{tabular}{|llll|}
\hline S.No. & Limiting value & category & No. of samples \\
\hline 1 & $<20$ & Excellent & 1 \\
2 & $20-40$ & Good & 35 \\
3 & $40-60$ & Permissible & 24 \\
4 & $60-80$ & Doubtful & - \\
5 & $>80$ & Unsuitable & - \\
\hline
\end{tabular}

into five types: unsuitable, doubtful, permissible, good and excellent. Percent sodium is computed using equation 2.

$$
\% \mathrm{Na}=\frac{\left(\mathrm{Na}^{+} \mathrm{K}^{+}\right) X 100}{\left(\mathrm{Ca}^{2+}+\mathrm{Mg}^{2+}+\mathrm{Na}^{+} \mathrm{K}^{+}\right)}
$$

All the samples in the study location are in $60 \%$, hence it falls in the range of excellent to permissible category (Table 5). As per sodium concentration, the groundwater does not have negative impacts like growth retardation or yield reduction. Table 5 shows the categorization of agricultural water quality based on percent sodium.

All the 60 samples fall in the group of excellent to permissible category. Wilcox diagram (Fig. 3) is used to assess the appropriateness of groundwater for irrigation using percent sodium and electric conductivity.

\section{Residual Sodium Carbonate}

Water with a carbonate concentration larger than the calcium and magnesium concentration is recognized by the term "residual sodium carbonate". Residual Sodium Carbonate (RCS) index refers to alkalinity hazard to the soil. If the sodium in clayey soil is higher, it causes swelling and reduces infiltration capacity. The potential of sodium vulnerability is

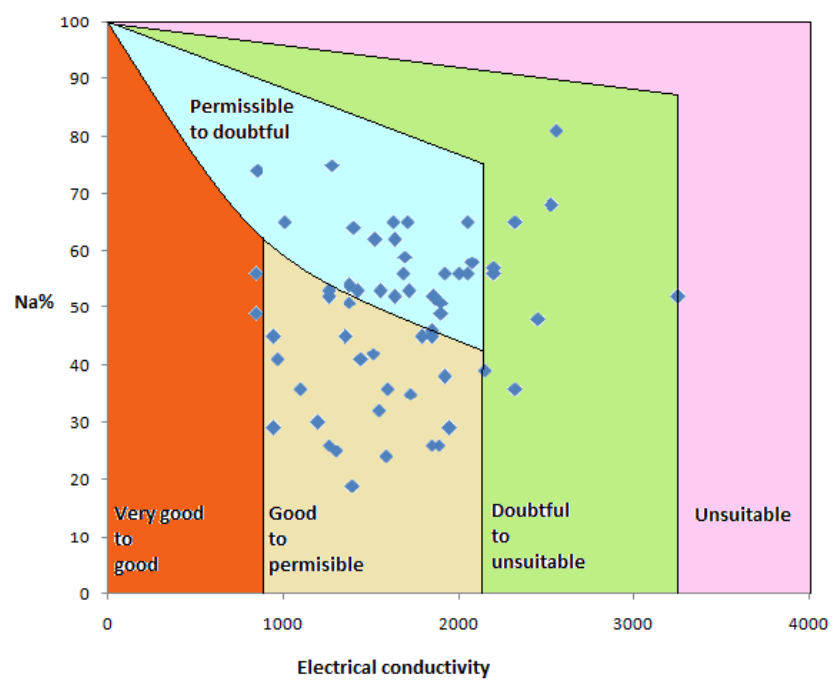

Fig. 3: Wilcox diagram for groundwater in the study area. 
Table 6: Classification of irrigation water quality based on RSC.

\begin{tabular}{|llll|}
\hline S.No & Limiting value & category & No. of samples \\
\hline 1 & $<1.25$ & Good & 58 \\
2 & $1.25-2.50$ & Doubtful & 2 \\
3 & $>2.50$ & Unsuitable & Nil \\
\hline
\end{tabular}

increased as Residual sodium carbonate (RSC) rises. Residual Sodium Carbonate (RSC) is calculated by the formula 3 .

$$
\mathrm{RSC}=\left(\mathrm{CO}_{3}^{2-}+\mathrm{HCO}_{3}^{-}\right)-\left(\mathrm{Ca}^{2+}+\mathrm{Mg}^{2+}\right)
$$

To identify the aptness of groundwater in clay soil, RCS index is used. If the groundwater with elevated RCS is applied for irrigation it leads to alkali soil formation. As per calculated RCS index for the 60 samples collected in the agricultural belt, 58 samples have low RCS value of less than 1.25 and are apt for irrigation as given in Table 6.

\section{Kelly's Ratio}

Sodium tested against calcium and magnesium is used to calculate Kelley's Ratio. Kelley Ratio indicates the highest value of sodium in the groundwater. The formula (4) is applied to calculate the Kelley's ratio.

$$
\mathrm{KR}=\frac{\mathrm{Na}^{+}}{\left(\mathrm{Ca}^{2+}+\mathrm{Mg}^{2+}\right)}
$$

Kelley's Ratio (KR) of more than 1 reveals an abundance level of sodium in waters. Subsequently, waters with Kelley's Ratio of less than one are most appropriate for irrigation, while those with a proportion of more than one are unacceptable for irrigation. Groundwater is classified based on KR and the results are given in Table 7. Sixty samples were analysed in the agricultural area and the Kelley ratio falls less than 1 for all the samples which indicate that the groundwater is good for irrigation in the study area.

\section{Magnesium Hazard}

Groundwater with elevated concentration of magnesium, if used for irrigation, damages soil structure and causes high salinity. Calcium and magnesium are present in water in an equilibrium state and they behave independently in the soil system. Magnesium hazard is given by equation 5 .

$$
\mathrm{MH}=\frac{\mathrm{Mg}^{+} \mathrm{X} 100}{\left(\mathrm{Ca}^{2+}+\mathrm{Mg}^{2+}\right)}
$$

From the analysis, $\mathrm{MH}$ value for the samples is in the

Table 7: Classification of irrigation water quality based on KR.

\begin{tabular}{|llll|}
\hline S.No & Limiting value & Category & No. of samples \\
\hline 1 & $<1$ & Suitable & 59 \\
2 & $>1$ & Unsuitable & 1 \\
\hline
\end{tabular}

Table 8: Categorization of irrigation water quality based on $\mathrm{MH}$.

\begin{tabular}{|llll|}
\hline S.No & Limiting value & Category & No. of samples \\
\hline 1 & $<50$ & Suitable & 9 \\
2 & $>50$ & Unsuitable & 51 \\
\hline
\end{tabular}

range of 35.68 to 77.89 . $\mathrm{MH}$ value should be less than 50. Out of 60 samples, 9 samples were apt for agriculture as per magnesium hazard as revealed in Table 8. If the magnesium hazard value is greater than 50 , it affects plant growth and becomes unsuitable for agricultural use. In most of the samples in the study area, i.e. in about 51 samples, the Magnesium Hazard value is above 50, which makes it unsuitable for agricultural use.

\section{Chloro Alkali Indices}

Groundwater chemistry is influenced by the ion exchange process. It is an important criterion for the mass transport of pollutants in aquifers and soils. Cation-anion exchange reaction takes place between the particles. Sodium and potassium ions exchange with calcium and magnesium in the presence of water. The CA I and CA II value may be positive or negative based on the reaction taking place. In the current study, 38 groundwater samples are with positive values which represents reverse ion exchange, and 22 samples of negative assessment indicating normal ion exchange.

\section{Total Hardness as $\mathrm{CaCO}_{3}$}

Hardness in water is brought about by the occurrence of divalent metallic cations like calcium, magnesium, ferrous iron, strontium, manganese and so on. It is relevant to take note that the greater part of the industrial sector in the zone, pre-treat water to evacuate hardness; else it blocks the working of their boilers. In the examination zone, 56 examples are in the class of hard to very hard (Table 9).

\section{Soluble Sodium Percent (SSP)}

Soluble Sodium Percent (SSP) for groundwater was determined using the formula 6 . The groupings of $\mathrm{Ca}^{2+}, \mathrm{Mg}^{2+}$ and $\mathrm{Na}^{+}$are articulated in milli equivalents per litre. The Solvent Sodium Percent (SSP) values of 50 or under 50 signify great quality water, and if in excess of 50, it denotes the intolerable water quality for irrigation (Kshetrimayum \& Bajpai 2012).

Table 9: Categorization of irrigation water quality based on $\mathrm{TH}$.

\begin{tabular}{|llll|}
\hline S.No & Limiting value & category & No. of samples \\
\hline 1. & $<75$ & Soft & 0 \\
2. & $75-150$ & Moderately hard & 3 \\
3. & $150-300$ & Hard & 36 \\
4. & $>300$ & Very hard & 20 \\
\hline
\end{tabular}




$$
\operatorname{SSP}=\frac{\mathrm{NaX} 100}{\mathrm{Ca}^{2+}+\mathrm{Mg}^{2+}+\mathrm{Na}^{+}}
$$

\section{Permeability Index}

Groundwater for irrigation was investigated dependent on the Permeability Index (PI). PI is computed from equation 7.

$$
\mathrm{PI}=\frac{\left(\mathrm{Na}^{+}+\sqrt{\left.\mathrm{HCO}_{3}\right)} \times 100\right.}{\left(\mathrm{Ca}^{2+}+\mathrm{Mg}^{2+}+\mathrm{Na}^{+}\right)}
$$

Accordingly, the permeability index is classified under class I, class II and class III as presented in Table 10. Class I and class II water samples are categorised as good. In the study area, 59 samples are in class I and II. Class III waters are non benefiting for agriculture with $25 \%$ of maximum permeability.

\section{Piper's Trilinear Diagram}

Piper Trilinear Diagram is used for depicting hydro substance attributes of groundwater. It is a standard strategy of anticipating hydro concoction facies, which is appropriate for arranging the water quality. Flautist chart created for the water quality is as shown in Fig. 3, and delineates likenesses and dissimilarities among the groundwater tests. Flautist outline comprises of 2 triangles, left triangle demonstrates cation and right triangle demonstrates anion, all the samples depicted in the triangle are in $\mathrm{meq} / \mathrm{L}$ and jewel shape in the

Table 10: Categorization of irrigation water quality based on PI.

\begin{tabular}{|llll|}
\hline S.No & Limiting value & Category & No. of samples \\
\hline 1 & $<25 \%$ & Class I & 1 \\
2 & $25-75 \%$ & Class II & 58 \\
3 & $>75 \%$ & Class III & 1 \\
\hline
\end{tabular}

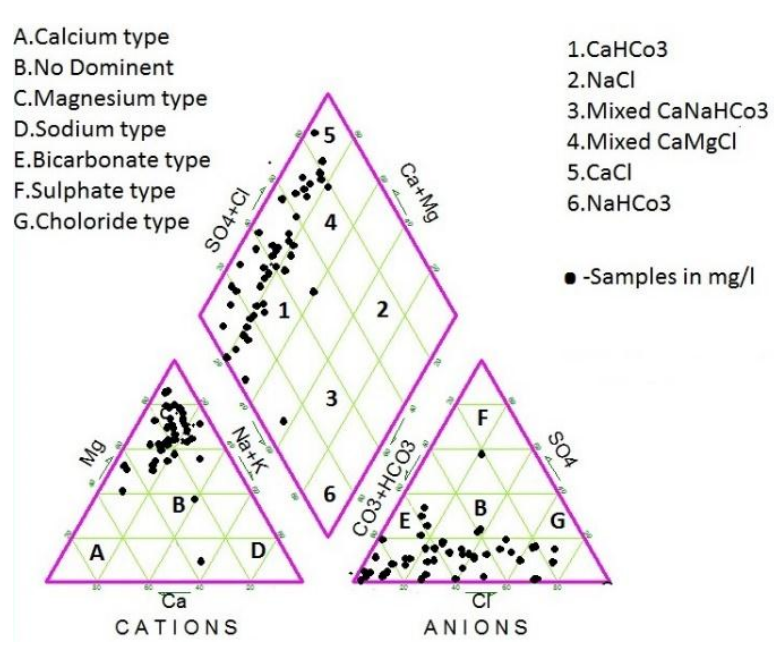

Fig. 4: Piper trilinear diagram.

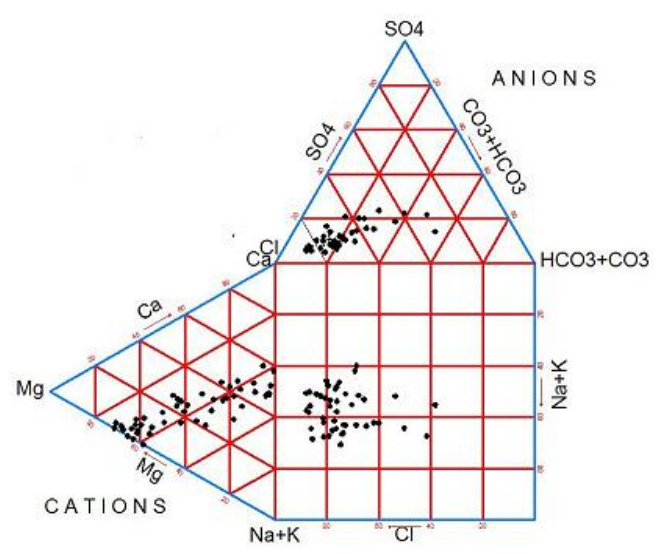

Fig. 5: Durov plot for cations and anions.

Piper Trilinear graph connotes both anion and cation field. All the 60 sampling stations were represented in the diagram. Rockworks16 software was used to create a piper trilinear diagram as shown in Fig. 4.

The input for constructing this diagram is $\mathrm{Ca}^{2+}, \mathrm{Mg}^{2+}$, $\mathrm{Na}^{+}, \mathrm{K}^{+}$, cations and anions are $\mathrm{HCO}_{3}{ }^{-}, \mathrm{CO}_{3}{ }^{2-}, \mathrm{Cl}^{-}$and $\mathrm{SO}_{4}{ }^{2-}$. The cation triangle reveals that dominating ion is magnesium as $92 \%$ of samples are in the $\mathrm{Mg}^{2+}$ portion, very few samples are under the no dominant nature and sodium nature. In the anionic regime, $\mathrm{Cl}$ dominates $\mathrm{HCO}_{3}{ }^{-}, \mathrm{CO}_{3}{ }^{2-}$ and $\mathrm{SO}_{4}{ }^{2-}$, very few samples fall in sulphate type. The yield from the Piper trilinear diagram chart proposes rock water interface and disintegration of rocks. Raised estimation of calcium hardness is expected to groundwater association with rocks and does not have a risky impact.

\section{Durov Diagram}

Most important ions like $\mathrm{Ca}^{2+}, \mathrm{Mg}^{2+}, \mathrm{HCO}_{3}{ }^{-}, \mathrm{CO}_{3}{ }^{2-}, \mathrm{Na}^{+}, \mathrm{K}^{+}$, $\mathrm{Cl}^{-}$and $\mathrm{SO}_{4}{ }^{2-}$ are considered for plotting Durov diagram and the trace elements are neglected for classification. Durov diagram is capable of classifying the water quality based on ionic concentration in the samples and the chemical composition of the water is given in Fig. 5. It has two base triangles and 1 square. All the cations and anions in the samples are projected as points in the triangular portion of the drawing. The plots in the triangular portion are transferred to the square grid.

The samples of similar ionic composition are clustered together. From the illustration $\mathrm{Cl}^{-}$dominated the $\mathrm{HCO}_{3}^{-}$, $\mathrm{CO}_{3}{ }^{2-}, \mathrm{SO}_{4}{ }^{2-}$ in the anionic plot. The cationic plot reveals that magnesium ions and calcium ions dominate the other cations. It is concluded from the plot, that the water quality in the study location is dominated by calcium and magnesium. The weathering of metamorphic rock and the hydrogeological framework in the study location might be the grounds for calcium-magnesium dominance. The 
dominance of ions in groundwater is of $\mathrm{Ca}, \mathrm{Mg}$ and $\mathrm{Cl}$ as per the Piper diagram.

\section{CONCLUSION}

Groundwater quality in the Coimbatore region is evaluated regarding groundwater system based on water quality parameters. The sequence of profusion of chemical deliberation is $\mathrm{Na}^{+}>\mathrm{Ca}^{2+}>\mathrm{Mg}^{2+}>\mathrm{K}^{+}=\mathrm{HCO}_{3}^{-}>\mathrm{Cl}^{-}>$ $\mathrm{NO}_{3}{ }^{-}$and $\mathrm{Ca}^{2+}>\mathrm{Mg}^{2+}>\mathrm{Na}^{+}>\mathrm{K}^{+}=\mathrm{HCO}_{3}{ }^{-}>\mathrm{Cl}^{-}>\mathrm{NO}_{3}{ }^{-}$. Strong acids $\left(\mathrm{SO}_{4}{ }^{2-}, \mathrm{Cl}^{-}\right)$overwhelm week acids $\left(\mathrm{HCO}_{3}^{-}\right.$, $\mathrm{CO}_{3}^{-2}$ ) in the study location. Elevated EC is limited in the length of upstream, and marginal in the downstream demonstrating the predominance of domestic, industrial and irrigational activities. High TH is noted in areas limited to the event of colouring and dying businesses. The larger part of groundwater tests are built up in $\mathrm{Ca}^{2+}-\mathrm{HCO}_{3}{ }^{-}$and blended $\mathrm{Ca}^{2+}-\mathrm{Mg}^{2+}-\mathrm{Cl}^{-}$. Very rarely some examples are found in zone 2, 3, which shows groundwater sort of $\mathrm{Na}^{+}-\mathrm{Cl}^{-}, \mathrm{Ca}^{2+}$. $\mathrm{Na}^{+}-\mathrm{HCO}_{3}{ }^{-}$separately. The water category is $\mathrm{Ca}-\mathrm{Mg}-\mathrm{Cl}$ type, as it is analysed by the Piper diagram. According to the Wilcox graph, the greater part of the example falls in the passable range. In the total samples of 60 tested, 11 samples location SAR value is below 6 . If the value is 6-9, the soil should be monitored and tested frequently for the increase of sodium. In 22 examples, SAR is more noteworthy and 9 samples are appropriate for irrigation. Magnesium risk is high in the examination territory. Demonstrating filtering and disintegration of salts throughout rainfall infiltrates into the aquifer matrix. The outcome uncovers that water quality falls in the classification of high in saltiness and low in SAR according to the USSL outline.

\section{REFERENCES}

Ahamed, A. Jafar, Loganathan, K. and Jayakumar, R. 2015. Hydrochemical characteristics and quality assessment of groundwater in Amaravathi River Basin of Karur District, Tamil Nadu, South India. Sustainable Water Resources Management, 1(3): 273-291.

Al-Ahmadi and Masoud Eid. 2013. Groundwater quality assessment in Wadi Fayd, Western Saudi Arabia. Arabian Journal of Geosciences, 6(1): 247-258.

APHA, 1998. Standard Methods for the Examination of Water and Wastewater. 20th Edition, American Public Health Association

Ayuba, R., Omonona, O.V. and Onwuka, O.S. 2013. Assessment of groundwater quality of Lokoja Basement Area, North-Central Nigeria. Journal of the Geological Society of India, 82(4): 413-420.

Basamba, Twaha, Kassim Sekabira, A., Mary Kayombo and Paul, Segawa 2013. Application of factor and cluster analyses in the assessment of sources of contaminants in borehole water in Tanzania. Pol. J. Environ. Stud., 22(2): 337-346.

BIS, 2009. Drinking Water-Specification, Bureau of Indian Standards. New Delhi.
Krishnasamy, R ., Shyamala, G., Johnson, S., Christian, Sabarinathan, K., Sakthivel, S. and Rajesh Kumar, K. 2020. Performance management of transmission line tower foundations against corrosion by non destructive testing. International Journal of Engineering and Advanced Technology, 9(3): 443-447.

Kshetrimayum, K. S. and Bajpai, V. N. 2012. Assessment of groundwater quality for irrigation use and evolution of hydrochemical facies in the Markanda River Basin, Northwestern India. Journal of the Geological Society of India, 79(2): 189-198.

Mohamed, Adam Khalifa, Dan Liu, Mohamed, A., A. Mohamed and Kai Song 2018. Groundwater quality assessment of the quaternary unconsolidated sedimentary basin near the Pi River using fuzzy evaluation technique. Applied Water Science, 8(2): 1-12.

Ramesh, S., Shyamala, G., Ramesh, N., Kalaivani, M., Mageshkumar, P. and Rajesh Kumar, K. 2020. Assessment of irrigation water quality in Orathupalayam Dam, Tamil Nadu, India. International Journal of Scientific \& Technology Research, 9(02): 5399-5403.

Ramkumar, Thirunavukkarasu, Senapathi Venkatramanan, Irudhayanathan Anithamary and Sheik Mohamed Syed Ibrahim 2013. Evaluation of hydrogeochemical parameters and quality assessment of the groundwater in Kottur Blocks, Tiruvarur District, Tamilnadu, India. Arabian Journal of Geosciences, 6(1): 101-108.

Salifu, Musah, Felix Aidoo, Michael Saah and Hayford Dickson 2015. Evaluating the suitability of groundwater for irrigational purposes in some selected districts of the upper west region of Ghana. Applied Water Science, 10.1007/s13201-015-0348-1

Sappa, Giuseppe, Sibel Ergul and Flavia Ferranti 2014. Water quality assessment of carbonate aquifers in Southern Latium Region, Central Italy : A case study for irrigation and drinking purposes. Applied Water Science, 4: 115-128.

Shanmugasundharam, A., Kalpana, G., Mahapatra, S. R., Sudharson, E. R. and Jayaprakash, M. 2015. Assessment of groundwater quality in Krishnagiri and Vellore Districts in Tamil Nadu, India. Applied Water Science, 10.1007/s13201-015-0361-4.

Shyamala, G. and Jeyanthi, J. 2017. Integrated weighted overlay model using inverse distance weightage for assessing groundwater quality. Journal of Environmental Science and Management, 20(1): 26-32.

Shyamala, G., Jeyanthi, J. and Gobinath, R. 2016. Nested hydrochemical and principle component analysis in predicting groundwater quality. Eco. Env. \& Cons., 22(1): 225-233.

Shyamala, G., Arun Kumar, B., Manvitha, S. and Vinay Raj, T. 2020. Assessment of spatial interpolation techniques on groundwater contamination. Springer International Publishing, http://dx.doi. org/10.1007/978-3-030-24314-2_33.

Shyamala, G., Shivanand, K. P. and Suresh Babu, S. 2008. A preliminary report on the physico-chemical nature of water pollution in and around Erode Town, Tamil Nadu. Nature Environment and Pollution Technology, 7(3): 555-559.

Shyamala, G., Shivanand, K. P. and Suresh Babu, S. 2008. Identification of pollution potential along Cauvery basin b satellite images. Nature Environment and Pollution Technology, 7(1): 93-95.

Srinivas, Y., Aghil, T. B., Hudson Oliver, D., Nithya Nair, C. and Chandrasekar, N. 2015. Hydrochemical characteristics and quality assessment of groundwater along the Manavalakurichi Coast, Tamil Nadu, India. Applied Water Science, 10.1007/s13201-015-0325-8.

Srinivasamoorthy, K., Vasanthavigar, M., Chidambaram, S., Anandhan, P., Manivannan, R. and Rajivgandhi, R. 2012. Hydrochemistry of groundwater from Sarabanga Minor Basin, Tamilnadu. Proceedings of the International Academy of Ecology and Environmental Sciences, 2(3): 193-203. 